\title{
Neuropharmacological Assessment of an Aqueous Bark Extract of Antiaris toxicaria (Pers.) Lesch. (Moraceae) in Rodents
}

\author{
Priscilla K. Mante, Donatus W. Adongo, \\ Kennedy K.E. Kukuia, Elvis O. Ameyaw and Eric Woode \\ Department of Pharmacology, Faculty of Pharmacy and Pharmaceutical Sciences, \\ College of Health Sciences, Kwame Nkrumah University of Science and Technology, Kumasi, Ghana
}

Received 2012-06-13, Revised 2012-07-01; Accepted 2012-11-26

\begin{abstract}
Antiaris toxicaria is a plant traditionally used in Ghana for the treatment of various neurological conditions such as epilepsy and pain. This present study therefore seeks to screen for the neuropharmacological activities of the aqueous extract of Antiaris toxicaria (AAE) stem bark. The effect of Antiaris extract on pentobarbital-induced sleeping time, tail immersion test, spontaneous locomotor activity, motor coordination, PTZ-induced convulsions as well as the Irwin test was investigated. The extract produced analgesia and Straub tail at (300-3000 mg kg$\left.{ }^{-1}\right)$ in the Irwin test suggestive of a morphine-like action. These effects were absent after $24 \mathrm{~h}$. No deaths were recorded in the test estimating the $\mathrm{LD}_{50}$ to be above $3000 \mathrm{mg}$ $\mathrm{kg}^{-1}$. Spontaneous locomotor activity of the mice in the activity meter test was decreased significantly $\left(\mathrm{p}<0.01, \mathrm{~F}_{4,20}=26.61\right)$ by the extract at $100 \mathrm{mg} \mathrm{kg}^{-1}$ but increased at $300-3000 \mathrm{mg} \mathrm{kg}^{-1}$. It however showed no impairment on motor coordination in the beam traversal test. The extract potentiated duration of sleeping time in the pentobarbitone interaction test and showed susceptibility to metabolism by hepatic enzymes. Analgesic properties were also further confirmed in the tail withdrawal test while it inhibited PTZ-induced convulsions. Thus, Antiaris may be a potential source for novel drug discovery in the field of neuropsychiatric research.
\end{abstract}

Keywords: Antiaris Toxicaria (AAE), Pentobarbitone (PBT), Phenobarbitone (PHE), Morphine Hydrochloride (MOR), International Conference on Harmonization (ICH)

\section{INTRODUCTION}

Antiaris toxicaria (Moraceae), commonly known as the Bark Cloth tree, is found in forests of Africa. The bark of this plant is used as an antiepileptic traditionally and seeds as an antipyretic and treatment for pain (Mshana et al., 2000). In Africa, the latex produced by the bark of A. toxicaria (Moraceae) is applied to cuts, wounds and skin conditions such as eczema and leprosy. It is also taken internally as a purgative (Bosu and Krampah, 2008). The latex serves as a component of most dart and arrow poisons in South East Asia. Antiaris is known to produce mainly prenylphenols
(Hano et al., 1990; 1991) and cardiac glycosides (Kiliani, 1910; Muhlradt et al., 1964; Carter et al., 1997a; 1997b). The species has been previously investigated and shown to be active against various cancer cell lines (Levrier et al., 2012; Li et al., 2012). However, there is no report on the psychopharmacological activity of this plant, although the decoctions of $A$. toxicaria are extensively used traditionally.

The present study was undertaken to investigate the CNS activity of Antiaris toxicaria extract in rodents. Methods employed in this study were adapted from the core battery of assessment of the central nervous system as proposed by the International

Corresponding Author: Eric Woode, Department of Pharmacology, Faculty of Pharmacy and Pharmaceutical Sciences, College of Health Sciences, Kwame Nkrumah University of Science and Technology, Kumasi, Ghana 
Conference on Harmonization (ICH) S7A Guideline for Safety Pharmacology (Anon, 2000). The guideline recommends the testing of novel compounds on the central and peripheral nervous system and on the cardiovascular system as part of the "core battery" of assessment (Williams et al., 2007). Rodents are mainly the species of choice for detecting behavioural and neurological effects. The mouse shares many anatomical, cellular, biochemical and molecular features with man. Other functions, such as memory, sexual behaviour and emotional responses are also similar. Based on these similarities, murine models are therefore employed to approximate human behavioural responses in disease states (Meer and Raber, 2005). Hence, this study involved the use of in vivo methods in freely moving conscious animals.

General behavioural observation, measures of spontaneous activity, locomotor activity, pain and convulsive thresholds in addition to interaction with hypnotics were assessed.

\section{MATERIALS AND METHODS}

\subsection{Plant Material}

The bark of Antiaris toxicaria was collected from the KNUST campus, Kumasi (6 $\left.6^{\circ} 41^{\prime} 6.4^{\prime \prime} \mathrm{N}, 1^{\circ} 33^{\prime} 42.8^{\prime \prime} \mathrm{W}\right)$, Ghana in March, 2010 where a voucher specimen (KNUST/HM1/011/S007) has been retained. Authentication was done at the Department of Herbal Medicine, KNUST.

\subsection{Preparation of Aqueous Extracts}

The Antiaris bark was air-dried at room temperature $\left(28^{\circ} \mathrm{C}\right)$ and powdered. Four hundred and thirty-one (431) gram powder was macerated with cold distilled water for five days. The filterate was concentrated under reduced temperature $\left(60^{\circ} \mathrm{C}\right)$ and pressure in a rotary evaporator. It was then oven-dried to obtain Antiaris Aqueous Extract (AAE). A yield of $23.40 \% \mathrm{w} / \mathrm{w}$ was obtained.

\subsection{Animals}

ICR mice (20-25 g) were obtained from the Noguchi Memorial Institute for Medical Research. Animals were kept in the departmental Animal House and allowed to acclimatize to laboratory conditions before the study. All animals were treated according to the Guide for the Care and Use of Laboratory Animals (ILAR, 1996) and experiments were approved by the Faculty Ethics Committee.

\subsection{Drugs and Chemicals}

Caffeine (CFN), Diazepam (DZP), Pentobarbitone (PBT), Pentylenetetrazole (PTZ) and Phenobarbitone (PHE) were purchased from Sigma-Aldrich Inc., St. Louis, MO, USA. Morphine hydrochloride (MOR) was obtained from Phyto-Riker Pharmaceuticals Limited, Accra, Ghana.

\subsection{Phytochemical Screening}

Antiaris toxicaria aqueous extract was tested for the presence of tannins, alkaloids, triterpenoids, flavonoids, general test for glycosides (reducing sugars), anthracene glycosides, steroids and saponins by simple quantitative and qualitative methods (Harborne, 1998; Trease and Evans, 1972).

\subsection{Irwin Test}

AAE was administered orally to male ICR mice at doses of $100-3000 \mathrm{mg} \mathrm{kg}^{-1}$ body weight in groups of seven. Behavioural, neurological and autonomic statuses were evaluated in each animal at $0,15,30,60,120$ and $180 \mathrm{~min}$, up to $48 \mathrm{~h}$ after treatment (Irwin, 1968; Williams et al., 2007).

\subsection{Activity Meter Test}

The Ugo Basile mouse activity cage (model 7401, Comerio, VA, Italy) was used in this test. Animals were first pre-treated with either AAE $\left(100-3000 \mathrm{mg} \mathrm{kg}^{-1}, p . o\right)$ or diazepam $\left(6 \mathrm{mg} \mathrm{kg}^{-1}\right.$, p.o) or caffeine $\left(18 \mathrm{mg} \mathrm{kg}^{-1}\right.$, p.o.). ICR mice were placed individually in the activity cage 60 min after AAE, diazepam or caffeine treatment. Activity was observed every 5-30 min.

\subsection{Beam Traversal Test}

Animals were randomly divided into seven groups consisting of five mice each and treated with extract (300-3000 mg kg-1, p.o.) or diazepam $(0.1,0.3$ and 1.0 $\mathrm{mg} \mathrm{kg}{ }^{-1}$, i.p). Animals were trained to traverse the beam (three consecutive trials each day for three days) to the goal box in less than $30 \mathrm{sec}$. Mice that could not achieve the goal were excluded from the study. During the test, mice were placed at the start end of the beam and allowed $60 \mathrm{sec}$ to traverse the beam. Test sessions were recorded with a video camera and analysed for total number of steps, time to traverse and stepping errors. A score of $60 \mathrm{sec}$ was awarded to animals which could not cross the beam or fell off. 


\subsection{Pentobarbitone Interaction Test}

Animals were randomly divided into eighteen groups comprising five mice each and treated with extract (300$3000 \mathrm{mg} \mathrm{kg}^{-1}$, p.o), diazepam $\left(8 \mathrm{mg} \mathrm{kg}^{-1}\right.$, i.p) or caffeine (16 $\mathrm{mg} \mathrm{kg}^{-1}$, i.p). Thirty minutes later, pentobarbitone $(50$ $\mathrm{mg} \mathrm{kg}{ }^{-1}$, i.p) was administered to each mouse to induce sleep. Mice were observed for the latency to sleep (time between pentobarbitone administration to loss of righting reflex) and duration of sleep (time between loss and recovery of righting reflex). Other groups of animals were pre-treated with phenobarbitone $\left(25 \mathrm{mg} \mathrm{kg}^{-1}\right.$, i.p) for two days prior to the testing day to investigate the effect of hepatic enzyme induction on sleeping time. Those animals were treated in the same manner as the naïve animals during testing.

\subsection{Tail Withdrawal Test}

The test was carried out according to the method described by (Janssen et al., 1963; Steinmiller and Young, 2008) with slight modifications. Tail withdrawal latency was defined as the time (in seconds) to withdraw the tail from hot water maintained at $50.0 \pm 1.0^{\circ} \mathrm{C}$. A cutoff latency of $10 \mathrm{~s}$ was set to avoid tissue damage. Increase in tail withdrawal latency was the measure of anti-nociception. It was calculated as:

$$
\% \text { Maximal Possible Effect }(\text { MPE })=\frac{\left[\left(\mathrm{T}_{1}-\mathrm{T}_{0}\right)\right]}{\left[\left(\mathrm{T}_{2}-\mathrm{T}_{0}\right)\right]} \times 100
$$

where, $\mathrm{T}_{0}$ and $\mathrm{T}_{1}$ are defined as the latencies obtained before and after drug treatment respectively and $T_{2}$ is the cut-off latency.

The maximum possible anti-nociceptive effect was awarded to animals that did not show a tail withdrawal reaction within $10 \mathrm{~s}$. Animals were tested at single time points of 60 min after administration of AAE (100-1000 $\mathrm{mg} \mathrm{kg}^{-1}$, p.o) and morphine (32-128 $\mathrm{mg} \mathrm{kg}^{-1}$, p.o).

\subsection{Convulsive Threshold Test (PTZ-Induced Seizures)}

Mice were divided into 7 groups $(n=7)$. The AAE was administered orally at $30-3000 \mathrm{mg} \mathrm{kg}^{-1}$. Other animals received diazepam $\left(0.3-3.0 \mathrm{mg} \mathrm{kg}^{-1}\right.$, i. p) while the control group received distilled water $\left(10 \mathrm{~mL} \mathrm{~kg}^{-1}\right)$. Seizures were induced with pentylenetetrazole $(85 \mathrm{mg}$ $\mathrm{kg}^{-1}$, s.c.) $30 \mathrm{~min}$ after distilled water or diazepam and 1 $\mathrm{h}$ after AAE. The mice were then observed via video recording for the frequency, duration of and latency to clonic convulsions for $1 \mathrm{~h}$.

\subsection{Data Analysis}

Significant differences between means were determined by Analysis of Variance (ANOVA) with Newman-Keuls' post hoc test. In the pentobarbitone interaction test, effect of treatment was determined by two-way ANOVA (Dose $\times$ treatment) followed by Bonferroni test. Graph Pad Prism ${ }^{\circledR}$ Version 5.0 (GraphPad Software, San Diego, CA, USA) was used for all statistical analyses. Values were presented as Mean \pm S.E.M. and in all cases, $\mathrm{p}<0.05$ was considered significant.

\section{RESULTS}

\subsection{Phytochemical Tests}

Phytochemical analysis of the stem bark of Antiaris toxicaria revealed the presence of the anthracene glycosides, tannins, flavonoids, alkaloids, saponins, reducing sugars and triterpenoids. Steroids were absent (Table 1).

\subsection{Irwin Test}

Acute dosing between $300-3000 \mathrm{mg} \mathrm{kg}^{-1}$ produced straub tail effect in the mice. Only the 1000 and $3000 \mathrm{mg}$ $\mathrm{kg}^{-1}$ doses parameters showed no changes and there were no deaths recorded in the Irwin test (Table 2).

\subsection{Activity Meter Test}

AAE showed significant $\left(p<0.01, \mathrm{~F}_{4,20}=26.61\right.$; Fig. 1b) decrease in locomotor activity at $100 \mathrm{mg} \mathrm{kg}^{-1}$ and a paradoxical increase at all other doses used mimicking effects of both diazepam and caffeine. Diazepam, (6 mg kg ${ }^{-1}$, p.o.), significantly ( $\mathrm{p}<0.001, \mathrm{~F}_{2,12}$ $=136.3$; Fig. 1b) decreased spontaneous activity while caffeine, $\left(18 \mathrm{mg} \mathrm{kg}^{-1}\right.$, p.o.) increased it.

\subsection{Beam Traversal Test}

No stepping errors were observed for all treatment groups in this test. The extract exhibited no significant change in the time taken to traverse the beam as well as the total number of steps as compared to the control.

Table 1. Phytochemical analysis of $A$. toxicaria aqueous extract

\begin{tabular}{lc}
\hline TEST & Results \\
\hline Anthracene glycosides & Present \\
Tannins & Present \\
Alkaloids & Present \\
Triterpenoids & Present \\
Flavonoids & Present \\
Saponins & Present \\
rrSteroids & Absent \\
\hline
\end{tabular}


Priscilla K. Mante et al. / American Journal of Pharmacology and Toxicology 7 (4) (2012) 123-134

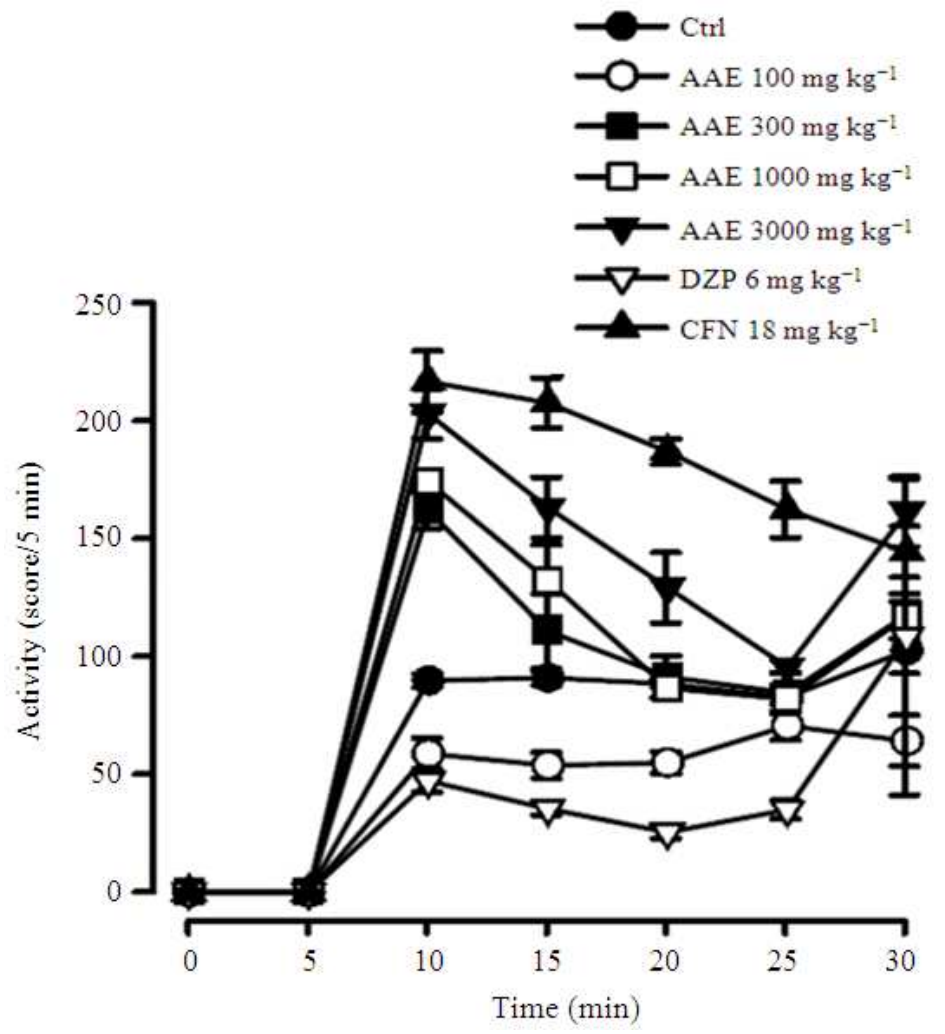

(a)

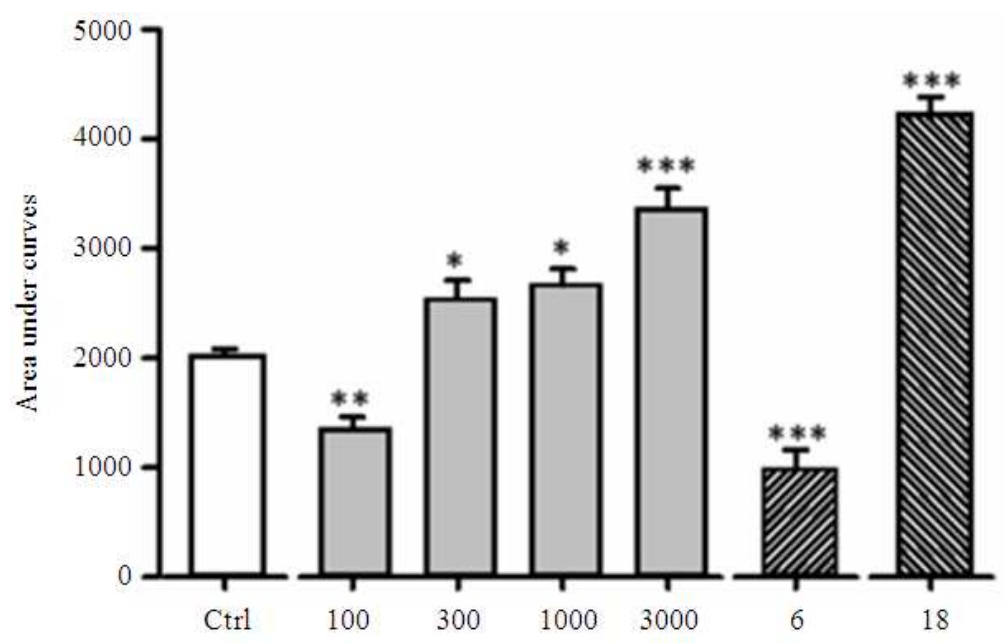

$\operatorname{AAE}\left(\mathrm{mg} \mathrm{kg}^{-1}\right) \quad$ DZP CFN

(b)

Fig. 1. Effects of acute $\operatorname{AAE}\left(100-3000 \mathrm{mg} \mathrm{kg}{ }^{-1}\right.$, p.o), diazepam $\left(6 \mathrm{mg} \mathrm{kg}^{-1}\right.$, p.o $)$ and caffeine $\left(18 \mathrm{mg} \mathrm{kg}^{-1}\right.$, p.o) treatment in the activity meter test. Data are presented as group means $( \pm$ SEM). Analysis by one-way ANOVA followed by Newman-Keuls' post hoc test. ${ }^{*} \mathrm{p}<0.05,{ }^{* *} \mathrm{p}<0.01,{ }^{* * *} \mathrm{p}<0.001$ 


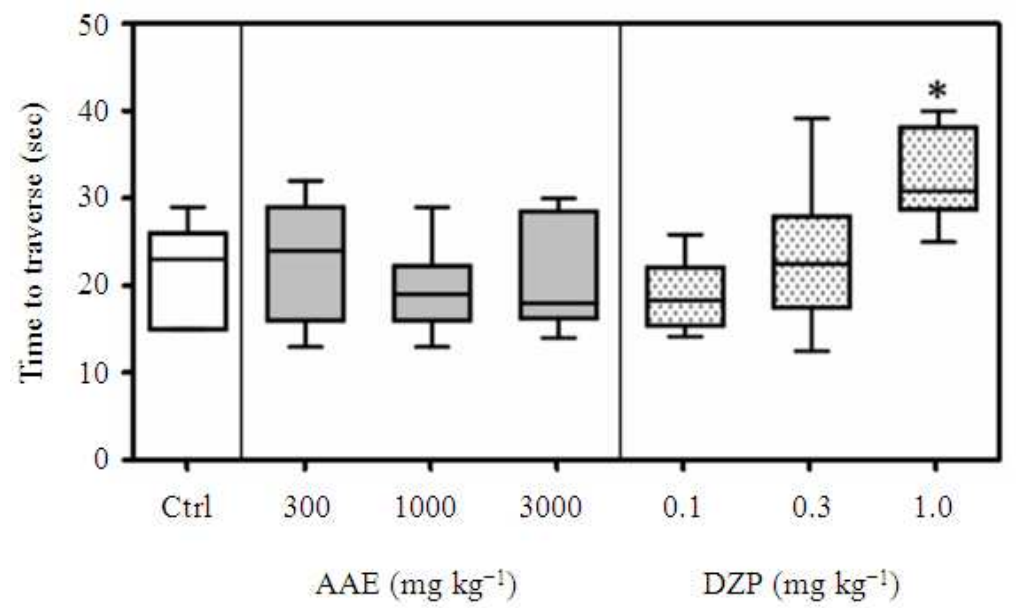

(a)

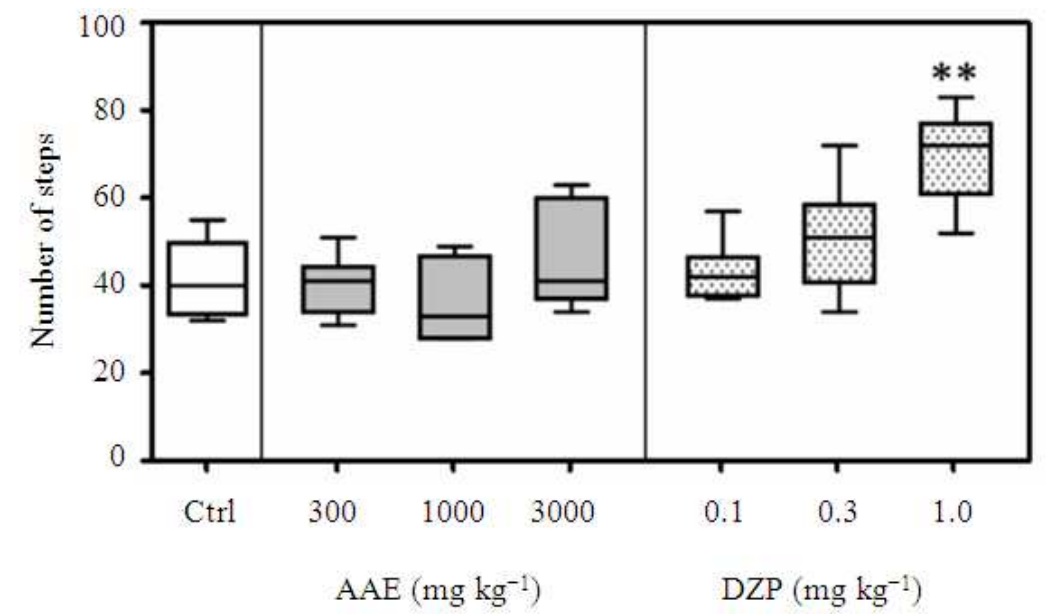

(b)

Fig. 2. Effects of $\operatorname{AAE}\left(300,1000\right.$ and $3000 \mathrm{mg} \mathrm{kg}^{-1}$, p.o) and diazepam (0.1, 0.3 and $1.0 \mathrm{mg} \mathrm{kg}^{-1}$, i.p) on the traversal time (a) and total number of steps taken (b) in the beam traversal test. Data are presented as group means $( \pm \mathrm{SEM})$. The lower and upper margins of the boxes represent the 25 and 75th percentiles, with the extended arms representing the 10th and 90th percentiles respectively. The median is shown as a horizontal line within the box. Analysis was done by one-way analysis of variance followed by Newman-Keuls' post hocTest. Significantly different from control: ${ }^{*} \mathrm{p}<0.05,{ }^{* *} \mathrm{p}<0.01$

Diazepam however at dose of $1 \mathrm{mg} \mathrm{kg}^{-1}$ showed a significant increase in both the time it took animals to traverse the beam $\left(p<0.05, F_{3}, 16=5.009\right.$, Fig. 2a) and the total number of steps taken $\left(p<0.01, F_{3}, 16=6.350\right.$, Fig. 2b).

\subsection{Pentobarbitone Interaction Test}

In the pentobarbitone interaction test, AAE significantly $\left(\mathrm{p}<0.001, \quad \mathrm{~F}_{1, \quad 8}=211.97\right.$ [Two-way ANOVA]; (Fig. 3a) prolonged the duration of sleeping time in test animals as compared to control. The onset of sleep was also significantly affected as it was reduced by $43.59 \%$ compared to saline- treated animals. Pre-treatment with phenobarbitone resulted in significant $\left(p<0.0001, F_{1,8}=39.8\right.$ [Two-way ANOVA]; Fig. 3b) decreases in the duration of sleep at dose levels 1000 and $3000 \mathrm{mg} \mathrm{kg}^{-1}$. Onset of sleep was not affected significantly by pretreatment with phenobarbitone. Sleep induced by diazepam was not significantly affected by either pentobarbitone or phenobarbitone.Sleep onset of caffeine was significantly $(\mathrm{p}<0.01)$ decreased by pentobarbitone administration but phenobarbitone pre-treatment had no effect. 


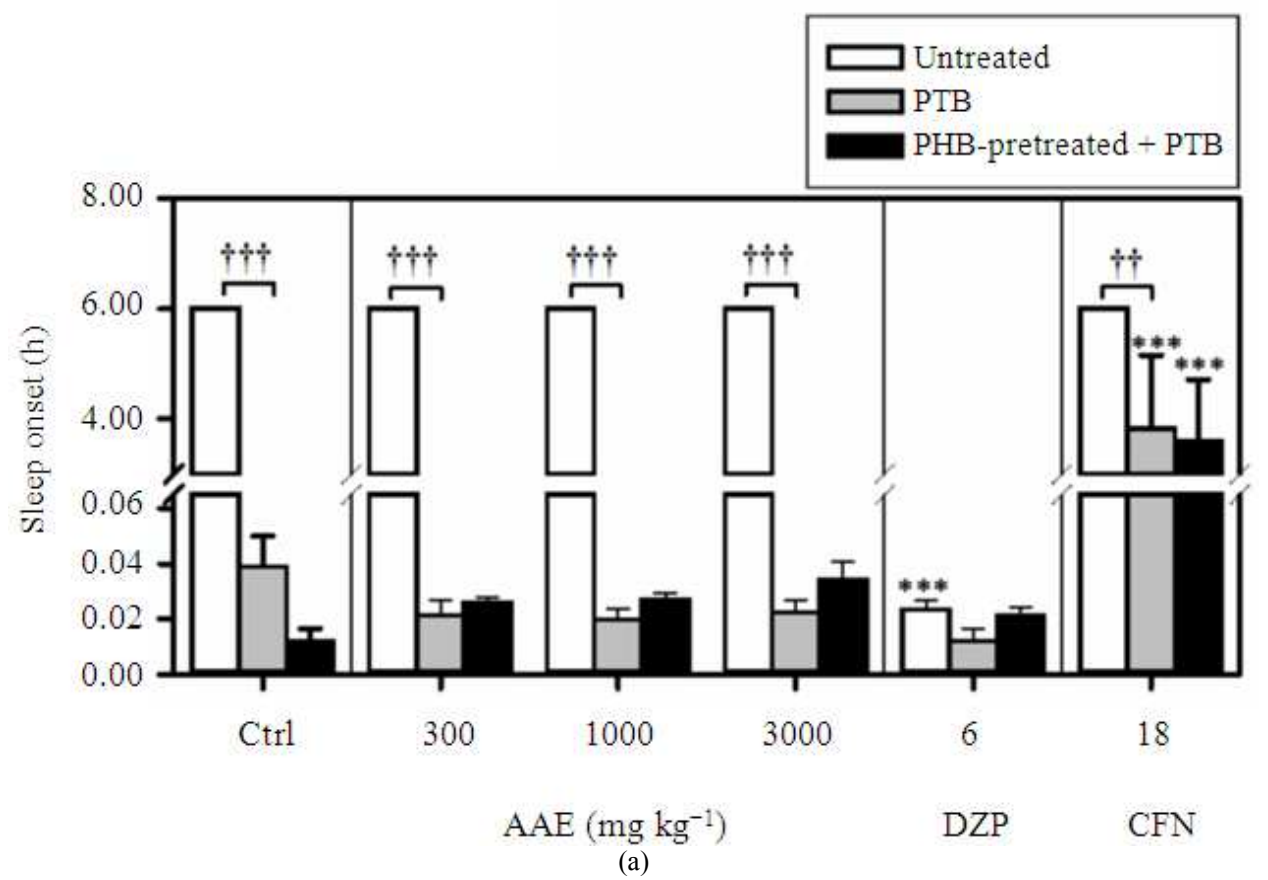

(a)

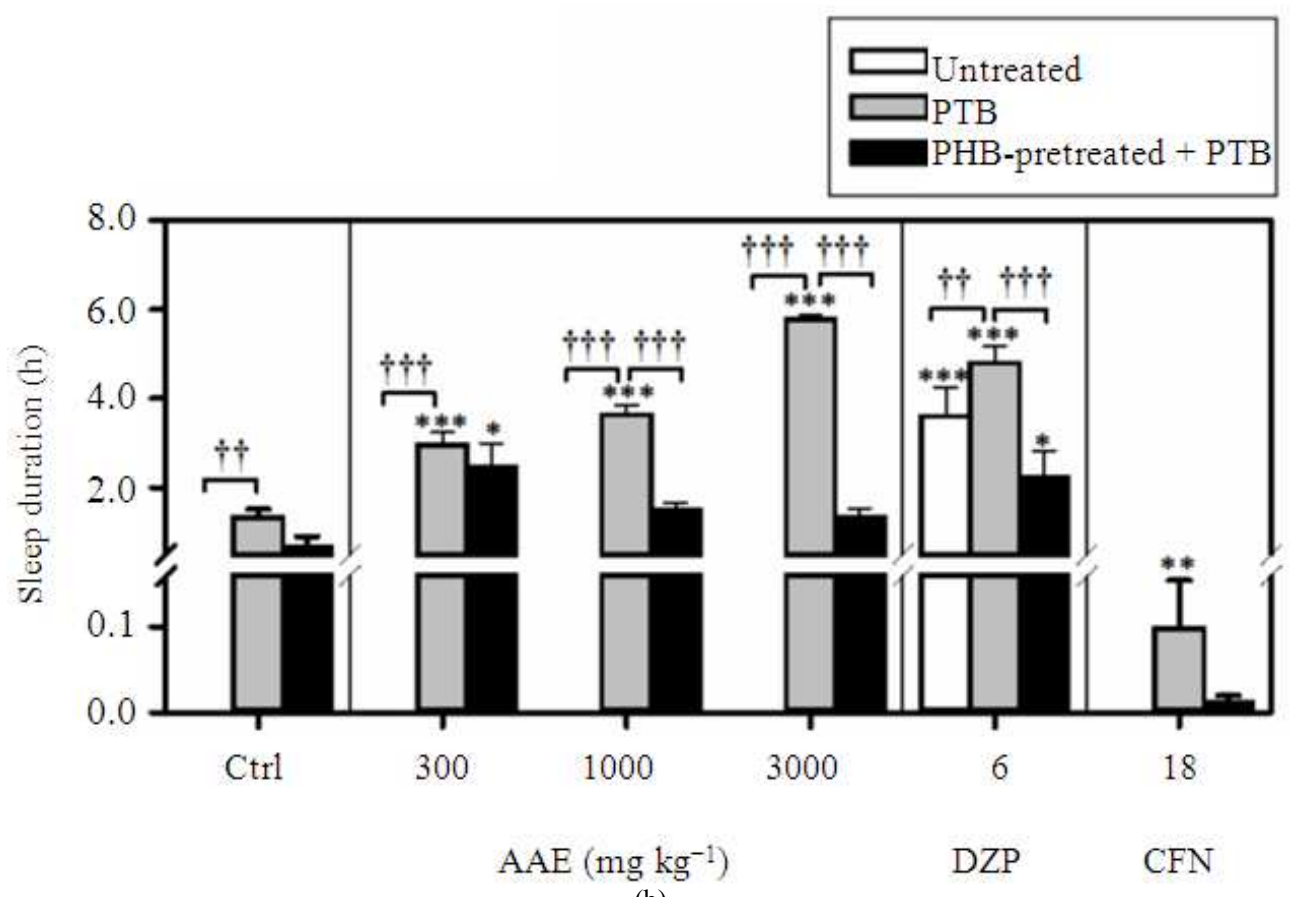

(b)

Fig. 3. Effects of acute $\operatorname{AAE}\left(300,1000\right.$ and $3000 \mathrm{mg} \mathrm{kg}^{-1}$, p.o), diazepam $\left(8 \mathrm{mg} \mathrm{kg}^{-1}\right.$, i.p) and caffeine $\left(16 \mathrm{mg} \mathrm{kg}^{-1}\right.$, i.p) in the Pentobarbital Interaction Test. Data are presented as group means $( \pm \mathrm{SEM})$. Analysis was done by one-way analysis of variance followed by Newman-Keuls' post hocTest. Significantly different from control: ${ }^{*} \mathrm{p}<0.05, * * \mathrm{p}<0.01$. ${ }^{* * *} \mathrm{p}<0.001$ and two-way ANOVA followed by Bonferroni test. $\dagger \uparrow \mathrm{p}<0.01, \uparrow \uparrow \uparrow \mathrm{p}<0.001$ 

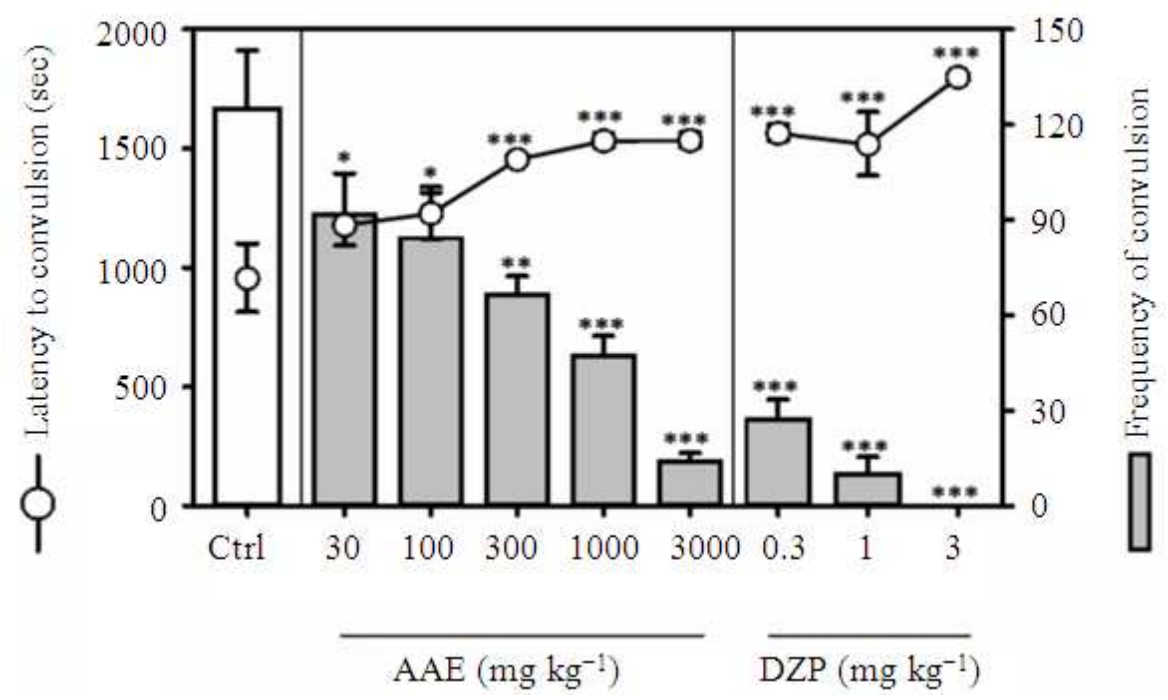

(a)

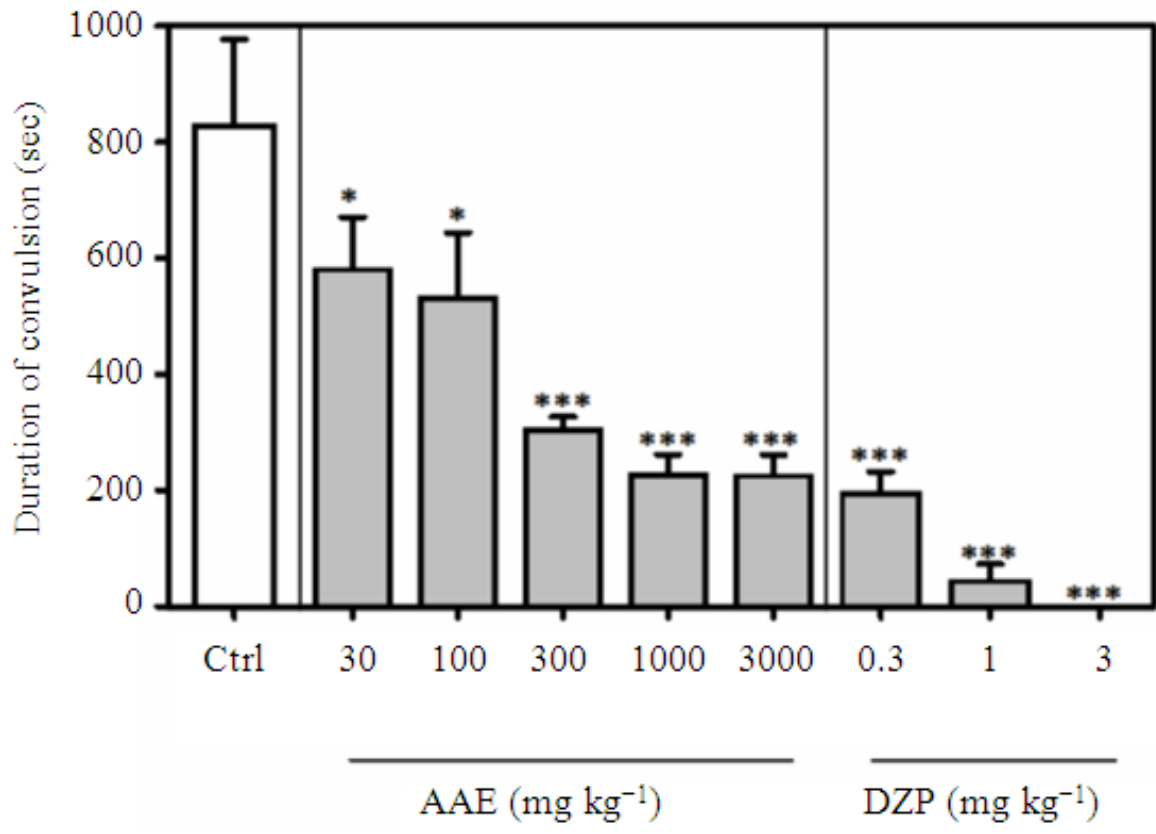

(b)

Fig. 4. Effects of $\operatorname{AAE}\left(30-3000 \mathrm{mg} \mathrm{kg}^{-1}\right.$, p.o.) and diazepam $\left(0.3,1.0\right.$ and $3.0 \mathrm{mg} \mathrm{kg}^{-1}$, i.p.) on the latency and frequency of seizures (a) and duration of convulsions (b) in PTZ - induced seizures. Data are presented as mean ( \pm SEM). Analysis was done by one-way analysis of variance followed by Newman-Keuls' post hocTest. Significantly different from control: ${ }^{*} \mathrm{p}<0.05$, $* * \mathrm{p}<0.01, * * * \mathrm{p}<0.001$

\subsection{Tail Withdrawal Test}

AAE increased tail withdrawal latency significantly $\left(\mathrm{p}<0.01, \mathrm{~F}_{3,28}=5.440\right)$ at all doses in a non- dose dependent anner. Similarly, morphine also showed marked increases $\left(p<0.001, F_{3,28}=38.38\right)$ in latency at all doses; effects which were greater than that of the extract (Table 3). 
Table 2. Effects of Antiaris toxicaria aqueous extract in the Irwin test

\begin{tabular}{lll}
\hline $\begin{array}{l}\text { DOSE } \\
\left(\mathrm{mg} \mathrm{kg}^{-1}\right)\end{array}$ & $\begin{array}{l}\text { Mortality } \\
----------\end{array}$ \\
\hline 0 & D/T & Effects \\
100 & $0 / 7$ & No change \\
300 & $0 / 7$ & No change \\
1000 & $0 / 7$ & $\begin{array}{l}\text { Straub tail at } 15^{\prime} \rightarrow 120^{\prime} \\
\text { Straub tail and Analgesia at } \\
15^{\prime} \rightarrow 120\end{array}$ \\
3000 & $0 / 7$ & $\begin{array}{l}\text { Straub tail and Analgesia at } \\
15^{\prime} \rightarrow 120\end{array}$ \\
\hline
\end{tabular}

Table 3. Effect of Antiaris toxicaria aqueous extract in the tail withdrawal test

\begin{tabular}{lll}
\hline Control & $\begin{array}{l}\text { Dose } \\
\left(\mathrm{mg} \mathrm{kg}^{-1}\right)\end{array}$ & $\begin{array}{l}\text { Percentage of maximal } \\
\text { possible effect }\end{array}$ \\
\hline \multirow{3}{*}{ AAE } & & $-20.27 \pm 15.29$ \\
& 100 & $48.52 \pm 14.53 *$ \\
Morphine & 300 & $48.80 \pm 15.49 * *$ \\
& 1000 & $44.27 \pm 12.44 * *$ \\
& 32 & $31.89 \pm 10.81 * * *$ \\
& 64 & $99.40 \pm 00.60 * * *$ \\
& 128 & $99.39 \pm 00.61 * * *$
\end{tabular}

*; $\mathrm{p}<0.05,{ }^{* *} ; \mathrm{p}<0.01,{ }^{* * *} ; \mathrm{p}<0.001$ by Newman-Keuls post hoc test

\subsection{Convulsive Threshold Test (PTZ-Induced Seizures)}

Onset of clonic convulsions were delayed by AAE significantly $\left(\mathrm{p}<0.0001, \mathrm{~F}_{5,36}=7.664\right.$; Fig. 4a) in mice. The frequency of convulsions likewise was reduced significantly $\left(p<0.0001, F_{5}, 36=11.46\right.$; Fig. 4a) in addition to the duration of clonic convulsions $\left(p<0.0001, F_{5,36}=8.043\right.$; Fig. 4b). The standard drug diazepam $\left(0.3-3.0 \mathrm{mg} \mathrm{kg}^{-1}\right)$ also significantly reduced and abolished convulsions.

\section{DISCUSSION}

Investigations carried out on the aqueous extract of Antiaris toxicaria show that it possesses CNS depressant activity and analgesia at high doses without muscle relaxant properties. It is also metabolized by hepatic enzymes and inhibits PTZ-induced convulsions.

In the Irwin test the extract exhibited potential analgesic properties to tail pinch responses as well as a Straub tail effect. The Irwin test involves systematic observational methods for assessing effects of drugs on the behaviour and physiology of rodents. It is a component of the basic protocols satisfying International Committee for Harmonization (ICH) recommendations for safety pharmacology studies. It was first described by Irwin (1968). It helps one detect potential adverse effects of drugs on the Central Nervous System (CNS) prior to clinical testing and may also be helpful in revealing novel therapeutic effects (Irwin, 1968; Porsolt et al., 2002; Williams et al., 2007). The Straub effect is often measured in response to opioids and has been shown to be mediated by the $\mu_{2}$-receptor (Nath et al., 1994; Houshyar et al., 2000). Other agonists have also been shown to be able to produce the said response by other mechanisms such as nicotinic and serotoninergic receptor activation (Duffard et al., 1995; Zarrindast et al., 2001; Fonck et al., 2003; Diaz and Maroteaux, 2011). This suggests possible opioidergic, serotoninergic or even nicotinic mechanisms of action. Since no deaths were recorded, the $\mathrm{LD}_{50}$ may be estimated to be above $3000 \mathrm{mg} \mathrm{kg}^{-1}$.

Pentobarbitone is a hypnotic at appropriate doses. Its sedation or hypnosis is by potentiation of GABAmediated postsynaptic inhibition at GABA receptors (Ffrench-Mullen et al., 1993; Brust, 2004). Potentiation of pentobarbitone-induced hypnosis is an indication of central depressant activity (Fujimori, 1965). Such substances either decrease the time for onset of sleep and/or prolong the duration of sleep. Diazepam was used as the positive control. It is a hypnotic belonging to the benzodiazepine group. The extract most likely possesses depressant action on the CNS similar to that of diazepam. Pretreatment with phenobarbitone for two days prior to testing induced liver metabolising enzymes (Ioannides and Parke, 1975; Whysner et al., 1996; Kushikata et al., 2003). Results indicate that the duration of sleep produced by the extract is shortened in the presence of metabolising enzymes. It is a strong indication that the extract might be broken down by cytochrome-P450 enzymes. This brings to the fore the possibility of drug interactions with other drugs that may be metabolised in the same manner since $60 \%$ of drugs are known to be metabolised by cytochrome-P450 enzymes (Zhou et al., 2005; Sweeney and Bromilow, 2006).

Testing for drug effect on motor coordination is a vital step in CNS drug evaluation. The beam traversal test helps to measure skilled walking, fine motor balance as well as coordination skills (Carter et al., 1999; Meredith and Kang, 2006). As such, increased errors in experiments indicate impaired motor coordination (Meredith and Kang, 2006). The extract showed no significant effect on motor coordination as shown by the results. Benzodiazepines at high doses have muscle relaxant effects (Woods and Winger, 1995; Charney et al., 2001) hence, the effect of diazepam on motor coordination. 
AAE however reduced spontaneous locomotor activity in mice in the activity meter test at $100 \mathrm{mg} \mathrm{kg}^{-1}$. Motor impairment that is drug- induced can result in decreased locomotor activity (Porsolt et al., 2002). Since motor impairment was absent in the beam traversal it can be ruled out as the cause of the reduction in locomotor activity observed. Another possible cause of reduced locomotion may be sedation which was not observed at any of the doses in the Irwin test. On the other hand, since the extract exhibited CNS depressant activity in the pentobarbitone interaction test, it may be safe to conclude on potential sedative effects since it is generally accepted that the sedative effects of drugs can be evaluated by measurement of pentobarbital sleeping time in laboratory animals (Brown, 1961; Carpenedo et al., 1994). Locomotion tests estimate whether a substance is psychostimulant or sedative. Substances with marked psychostimulant properties are expected to increase locomotor activity (Riviere et al., 1999; Kafkafi et al., 2001; Gentry et al., 2004). But can cause a decrease due to animals rotating rapidly in a small space or showing stereotyped behaviours (Morita et al., 2000; Quinn et al., 2003). The increase in locomotor activity at higher doses may be due to some increased exploratory behaviour that may be evident with anxiolytic compounds such as these benzodiazepines (Turski et al., 1982). But this is in contrast to benzodiazepines that produce increased spontaneous activities at low doses and sedation at much higher doses. Diazepam, a CNS depressant, reduced spontaneous activity (Savic et al., 2003) and impaired motor coordination at the dose used while caffeine, a CNS stimulant, increased the locomotor activity (Kafkafi et al., 2001; Gentry et al., 2004).

The extract also had a significant effect in the tail withdrawal test. This test is considered to model somatosensory pain (Bjorkman, 1995; Shannon et al., 1997; Kalra et al., 2001) and known to be more sensitive to centrally acting analgesics (Prado et al., 1990; Gupta et al., 2005; Santos et al., 2005). Such agents act to elevate pain threshold of animals towards heat and pressure. Central activity involves spinal and supra spinal mechanisms which can be conferred on the extract since it exhibited significant activity in this model (Jain et al., 2001; Muhammad et al., 2012).

Finally, the extract produced significant inhibition of PTZ-induced seizures which helps to confirm its traditional use in epilepsy management. One of the generally accepted mechanisms by which pentylenetetrazole exerts its action is by acting as an antagonist at the $\mathrm{GABA}_{\mathrm{A}}$ receptor complex (Ramanjaneyulu and Ticku, 1984; Katzung, 2004). GABA is a major inhibitory neurotransmitter in the mammalian central nervous system (Katzung, 2004). Inhibition of pentylenetetrazole-induced seizures is an indication that the effects of Antiaris toxicaria may be associated with modulation of GABA activity in the central nervous system. This may not be surprising as it has demonstrated significant central depressant properties.

\section{CONCLUSION}

The overall results from this study show that AAE possesses CNS depressant, analgesic and anticonvulsant activity. It also can increase spontaneous activity without motor impairment and its $\mathrm{LD}_{50}$ may be above $3000 \mathrm{mg} \mathrm{kg}^{-1}$.

\section{REFERENCES}

Anon, 2000. ICH S7A: Safety Pharmacology studies for human pharmaceuticals. European Agency for the Evaluation of Medicinal Products, London.

Bjorkman, R., 1995. Central antinociceptive effects of non-steroidal anti-inflammatory drugs and paracetamol. Experimental studies in the rat. Acta Anaesthesiol. Scand Suppl., 103: 1-44. PMID: 7725891

Bosu, P.P. and E. Krampah, 2008. Antiaris Toxicaria Lesch. In: Bois D'oeuvre 1, D. Louppe, (Ed.)., PROTA, Weikersheim, ISBN-10: 9057822113.

Brown, A.M., 1961. Sleeping time responses of mice-random bred, inbred and F1 hybrids--to pentobarbitone sodium. J. Pharm. Pharmacol., 13: 679-687. PMID: 13873578

Brust, J.C.M., 2004. Neurological Aspects of Substance Abuse. 2nd Edn., Elsevier, Philadelphia, PA., ISBN10: 0750673133, pp: 477.

Carpenedo, R., A. Chiarugi, P. Russi, G. Lombardi and V. Carla et al., 1994. Inhibitors of kynurenine hydroxylase and kynureninase increase cerebral formation of kynurenate and have sedative and anticonvulsant activities. Neuroscience, 61: 237243. PMID: 7969905

Carter, C.A., E.A. Gray, T.L. Schneider, C.M. Lovett and L. Scott et al., 1997a. Toxicarioside B and toxicarioside C. New cardenolides isolated from Antiaris toxicaria latex-derived dart poison. Tetrahedron, 53: 16959-16968. DOI: 10.1016/S0040-4020(97)10174-0 
Carter, C.A., R.W. Forney, E.A. Gray, A.M. Gehring and T.L. Schneider et al., 1997b. Toxicarioside A. A new cardenolide isolated from Antiaris toxicaria latex-derived dart poison. Assignment of the ${ }^{1} \mathrm{H}$ - and ${ }^{13} \mathrm{C}-\mathrm{NMR}$ shifts for an antiarigenin aglycone. Tetrahedron, 53: 13557-13566. DOI: 10.1016/S0040-4020(97)00895-8

Carter, R.J., L.A. Lione, T. Humby, L. Mangiarini and A. Mahal et al., 1999. Characterization of progressive motor deficits in mice transgenic for the human Huntington's disease mutation. J. Neurosci., 19: 3248-3257. PMID: 10191337

Charney, D.A., A.M. Paraherakis and K.J. Gill, 2001. Integrated treatment of comorbid depression and substance use disorders. J. Clin. Psychiatry, 62: 672677. PMID: 11681761

Diaz, S.L. and L. Maroteaux, 2011. Implication of 5$\mathrm{HT}_{2 \mathrm{~B}}$ receptors in the serotonin syndrome. Neuropharmacology, 61: 495-502. DOI: 10.1016/j.neuropharm.2011.01.025

Duffard, A.M.E.D., A. Bortolozzi and R.O. Duffard 1995. Altered behavioral responses in 2,4dichlorophenoxyacetic acid treated and amphetamine challenged rats. Neurotoxicology, 16: 479-488. PMID: 8584279

Ffrench-Mullen, J.M., J.L. Barker and M.A. Rogawski, 1993. Calcium current block by (-)-pentobarbital, phenobarbital and CHEB but not (+)-pentobarbital in acutely isolated hippocampal CA1 neurons: Comparison with effects on GABA-activated Clcurrent. J. Neurosci., 13: 3211-3221. PMID: 8101867

Fonck, C., R. Nashmi, P. Deshpande, M.I. Damaj and M.J. Marks et al., 2003. Increased sensitivity to agonist-induced seizures, straub tail and hippocampal theta rhythm in knock-in mice carrying hypersensitive alpha 4 nicotinic receptors. J. Neurosci., 23: 2582-2590. PMID: 12684443

Fujimori, H., 1965. Potentiation of barbital hypnosis as an evaluation method for central nervous system depressants. Psychopharmacologia, 7: 374-378. PMID: 5837313

Gentry, W.B., A.U. Ghafoor, W.D. Wessinger, E.M. Laurenzana and H.P. Hendrickson et al., 2004. (+)Methamphetamine-induced spontaneous behavior in rats depends on route of $(+)$ METH administration. Pharmacol. Biochem. Behav., 79: 751-760. PMID: 15582684
Gupta, M., U.K. Mazumder, R.S. Kumar, P. Gomathi and Y. Rajeshwar et al., 2005. Anti-inflammatory, analgesic and antipyretic effects of methanol extract from Bauhinia racemosa stem bark in animal models. J. Ethnopharmacol., 98: 267-273. PMID: 15814258

Hano, Y., P. Mitsui and T. Nomura, 1990. Seven prenylphenols, antiarones $\mathrm{C}, \mathrm{D}, \mathrm{E}, \mathrm{F}, \mathrm{G}, \mathrm{H}$ and I from the root bark of Antiaris toxicaria lesch. Heterocycles, 31: 1315-1323.

Hano, Y., P. Mitsui, T. Nomura, T. Kawai and Y. Yoshida, 1991. Two new dihydrochalcone derivatives, antiarones $\mathrm{J}$ and $\mathrm{K}$, from the root bark of Antiaris toxicaria. J. Nat. Prod., 54: 1049-1055. DOI: $10.1021 / \mathrm{np50076a020}$

Harborne, A.J., 1998. Phytochemical Methods a Guide to Modern Techniques of Plant Analysis. 3rd Edn., Springer, London, ISBN-10: 0412572605, pp: 320.

Houshyar, H., I.J. Mc Fadyen, J.H. Woods and J.R. Traynor, 2000. Antinociceptive and other behavioral effects of the steroid SC17599 are mediated by the $\mu$-opioid receptor. Eur. J. Pharmacol., 395: 121-128. DOI: 10.1016/S0014-2999(00)00176-X

ILAR, 1996. Guide for the Care and Use of Laboratory Animals. 7th Edn., National Academies Press, Washington, D.C., ISBN-10: 0309053773, pp: 125.

Ioannides, C. and D.V. Parke, 1975. Mechanism of induction of hepatic microsomal drug metabolizing enzymes by a series of barbiturates. J. Pharm. Pharmacol., 27: 739-746. PMID: 241786

Irwin, S., 1968. Comprehensive observational assessment: Ia. A systematic, quantitative procedure for assessing the behavioral and physiologic state of the mous. Psychopharmacologia, 13: 222-257. PMID: 5679627

Jain, N.K., S.K. Kulkarni and A. Singh, 2001. Role of cysteinyl leukotrienes in nociceptive and inflammatory conditions in experimental animals. Eur. J. Pharmacol., 423: 85-92. PMID: 11438310

Janssen, P.A., C.J. Niemegeers and J.G. Dony, 1963. The inhibitory effect of fentanyl and other morphine-like analgesics on the warm water induced tail withdrawl reflex in rats. Arzneimittelforschung, 13: 502-507. PMID: 13957426

Kafkafi, N., C. Mayo, D. Drai, I. Golani and G. Elmer, 2001. Natural segmentation of the locomotor behavior of drug-induced rats in a photobeam cage. J. Neurosci. Methods, 109: 111-21. DOI: 10.1016/S0165-0270(01)00392-2 
Kalra, A., M.O. Urban and K.A. Sluka, 2001. Blockade of opioid receptors in rostral ventral medulla prevents antihyperalgesia produced by Transcutaneous Electrical Nerve Stimulation (TENS). J. Pharmacol. Exp. Ther., 298: 257-263. PMID: 11408550

Katzung, B.G., 2004. Basic and Clinical Pharmacology. 9th Edn., McGraw-Hill Inc., Boston, ISBN-10: 0071440976, pp: 1202.

Kiliani, H., 1910. Uber den Milchsaft von Antiaris toxicaria. Berichte Deutschen Chem. Gesellschaft, 43: 3574-3579. DOI: 10.1002/cber. 191004303150

Kushikata, T., K. Hirota, H. Yoshida, M. Kudo and D.G. Lambert et al., 2003. Orexinergic neurons and barbiturate anesthesia. Neuroscience, 121: 855-863. PMID: 14580935

Levrier, C., B. Kiremire, F. Gueritte and M. Litaudon, 2012. Toxicarioside $M$, a new cytotoxic 10ßhydroxy-19-nor-cardenolide from Antiaris toxicaria. Fitoterapia, 83: 660-664. PMID: 22348979

Li, Y.N., F.Y. Huang, W.L. Mei, H.F. Dai and J.L. Guo et al., 2012. Toxicarioside A, isolated from tropical Antiaris toxicaria, blocks endoglin/TGF- $\beta$ signaling in a bone marrow stromal cell line. Asian Pac. J. Trop Med., 5: 91-97. PMID: 22221748

Meer, P.V. and J. Raber, 2005. Mouse behavioural analysis in systems biology. Biochem. J., 389: 593610. PMID: 16035954

Meredith, G.E. and U.J. Kang, 2006. Behavioral models of Parkinson's disease in rodents: A new look at an old problem. Mov Disord., 21: 1595-1606. PMID: 16830310

Morita, T., R. Sonoda, K. Nakato, K. Koshiya and F. Wanibuchi et al., 2000. Phencyclidine-induced abnormal behaviors in rats as measured by the hole board apparatus. Psychopharmacology, 148: 281288. PMID: 10755741

Mshana, R.N., D.K. Abbiw, I. Addae-Mensah, E. Adjanouhoun and M.R.A. Ahyi et al., 2000. Traditional Medicine and Pharmacopoeia: Contribution to the Revision of Ethnobotanical and Floristic Studies in Ghana. 1st Edn., Organization of African Unity/Scientific, pp: 90.

Muhammad, N., M. Saeed and H. Khan, 2012. Antipyretic, analgesic and anti-inflammatory activity of Viola betonicifolia whole plant. BMC Complement Altern Med., 12: 59-59. PMID: 22551220
Muhlradt, P., E. Weiss and T. Reichstein, 1964. Die Cardenolide der Samen von Antiaris toxicaria Lesch. 1. Mitteilung: Isolierungen und Identifizierungen Glykoside und Aglykone, 258. Mitteilung. Helvetica Chim. Acta, 47: 2164-2186. DOI: $10.1002 /$ hlca. 19640470810

Nath, C., M.B. Gupta, G.K. Patnaik and K.N. Dhawan, 1994. Morphine-induced straub tail response: Mediated by central $\mu_{2}$-opioid receptor. Eur. J. Pharmacol., 263: 203-205. DOI: 10.1016/00142999(94)90543-6

Porsolt, R.D., M. Lemaire, N. Durmuller and S. Roux, 2002. New perspectives in CNS safety pharmacology. Fundam Clin. Pharmacol., 16: 197207. PMID: 12165067

Prado, W.A., C.R. Tonussi, E.M. Rego and A.P. Corrado, 1990. Antinociception induced by intraperitoneal injection of gentamicin in rats and mice. Pain, 41: 365-371. PMID: 2388773

Quinn, L.P., T.O. Stean, B. Trail, M.S. Duxon and S.C. Stratton et al., 2003. LABORAS: Initial pharmacological validation of a system allowing continuous monitoring of laboratory rodent behaviour. J. Neurosci. Methods, 130: 83-92. PMID: 14583407

Ramanjaneyulu, R. and M.K. Ticku, 1984. Interactions of pentamethylenetetrazole and tetrazole analogues with the picrotoxinin site of the benzodiazepineGABA receptor-ionophore complex. Eur. J. Pharmacol., 98: 337-345. PMID: 6327331

Riviere, G.J., K.A. Byrnes, W.B. Gentry and S.M. Owens, 1999. Spontaneous locomotor activity and pharmacokinetics of intravenous methamphetamine and its metabolite amphetamine in the rat. J. Pharmacol. Exp. Ther., 291: 1220-1226. PMID: 10565845

Santos, F.A., F.A. Jeferson, C.C. Santos, E.R. Silveira and V.S. Rao, 2005. Antinociceptive effect of leaf essential oil from Croton sonderianus in mice. Life Sci., 77: 2953-2963. PMID: 15979097

Savic, M.M., D.I. Obradovic, N.D. Ugresic and D.R. Bokonjic, 2003. The influence of diazepam on atropine reversal of behavioural impairment in dichlorvos-treated rats. Pharmacol. Toxicol., 93: 211-218. PMID: 14629732

Shannon, H.E., D.E. Womer, F.P. Bymaster, D.O. Calligaro and N.C. DeLapp et al., 1997. In vivo pharmacology of butylthio[2.2.2] (LY297802/NNC11-1053), an orally acting antinociceptive muscarinic agonist. Life Sci., 60: 969-976. PMID: 9121363 
Steinmiller, C.L. and A.M. Young, 2008. Pharmacological selectivity of CTAP in a warm water tail-withdrawal antinociception assay in rats. Psychopharmacology, 195: 497-507. DOI: 10.1007/s00213-007-0898-5

Sweeney, B.P. and J. Bromilow, 2006. Liver enzyme induction and inhibition: Implications for anaesthesia. Anaesthesia, 61: 159-177. DOI: 10.1111/j.1365-2044.2005.04462.x

Trease, G.E. and W.C. Evans, 1972. Pharmacognosy. 10th Edn., Bailliere Tindall, London, ISBN-10: 8131200876, pp: 795.

Turski, L., M. Schwarz and K.H. Sontag, 1982. Interaction between phenytoin and diazepam in mutant Han-Wistar rats with progressive spastic paresis. Naunyn Schmiedebergs Arch Pharmacol., 32: 48-51. PMID: 7144926

Whysner, J., P.M. Ross and G.M. Williams, 1996. Phenobarbital mechanistic data and risk assessment: Enzyme induction, enhanced cell proliferation and tumor promotion. Pharmacol. Ther., 71: 153-191. DOI: $10.1016 / 0163-7258(96) 00067-8$
Williams, M., R.D. Porsolt and P. Lacroix, 2007. Safety Pharmacology II-CV, GI, Respiratory and Renal Safety. xPharm: Comprehensive Pharmacol. Ref. DOI: 10.1016/B978-008055232-3.63692-X

Woods, J.H. and G. Winger, 1995. Current benzodiazepine issues. Psychopharmacology, 118: 107-115. PMID: 7617794

Zarrindast, M.R., K. Alaei-Nia and M. Shafizadeh, 2001. On the mechanism of tolerance to morphine-induced Straub tail reaction in mice. Pharmacol. Biochem. Behav., 69: 419-424. DOI: 10.1016/S00913057(01)00519-6

Zhou, S., S.Y. Chan, B.C. Goh, E. Chan and W. Duan et al., 2005. Mechanism-based inhibition of cytochrome P450 3A4 by therapeutic drugs. Clin. Pharmacokinet, 44: 279-304. PMID: 15762770 